\title{
Production and Optimization of Protease by Filamentous Fungus Isolated from Paddy Soil in Thiruvarur District Tamilnadu
}

\author{
Sudarkodi Chandrasekaran ${ }^{1}$, Sundar Sundaram Pillai Kumaresan ${ }^{1}$, Murugan Manavalan ${ }^{2 *}$ \\ ${ }^{1}$ Department of Microbiology, M.R. Govt. Arts College, Mannargudi, Tiruvarur, Tamil Nadu-641 014, India. \\ ${ }^{2}$ Centre for Biological Science, Noorul Islam University, Tamil Nadu-629 180, India.
}

\section{ARTICLE INFO}

Article history:

Received on: 16/10/2015

Revised on: 01/11/2015

Accepted on: 28/11/2015

Available online: 19/12/2015

Key words:

Protease, $\mathrm{pH}$, temperature,

Aspergillus flavus and

Aspergillus niger.

\begin{abstract}
This study was under taken to monitor the production of protease enzyme from paddy field soil fungal isolates obtained from Mannargudi, Tamil Nadu. The study also sought to optimize the kinetic parameters of the enzyme with the aim of establishing large scale production of it. Two isolates Aspergillus flavus and Aspergillus niger out of the six were opted as potential candidates for enzyme production following the screening method of plate assay. The results observed were for the maximal production of enzyme by the isolates at various temperatures and $\mathrm{pH}$. Aspergillus flavus and Aspergillus niger showed highest activity in the optimized medium at $\mathrm{pH} 8.0$ and temperature $30^{\circ} \mathrm{C}, \mathrm{pH} 7.0$ and temperature $35^{\circ} \mathrm{C}$, respectively.
\end{abstract}

\section{INTRODUCTION}

The microbial proteases of Aspergillus species, in particular, have been studied in detail since they are known for their capacity to secrete high levels of enzymes in their growth environment. Several of these secreted enzymes, produced in a large-scale submerged fermentation, have been widely used in the food and beverage industry for decades [1]. Filamentous fungi can effectively secrete various hydrolytic enzymes and one of the main groups of secreted enzymes in fungi is protease. For the microbial and biological activities soil is a dynamic medium and the number and kind of microorganisms present in soil depends on environmental factors [2]. Microorganisms are the most common sources of commercial enzymes due to their physiological and biochemical properties, facile culture conditions and ease of cell manipulation [3]. In the last three decades there has been a spectacular rise in the production of industrial enzymes. The growth of industrial enzyme market has expanded to nearly 85 enzymes, which are currently in commercial production. The protease enzyme constitutes two thirds of total enzymes used in various industries and this dominance in the industrial market is expected to increase as year gone-by [4]. Microbial proteases are preferred to plant and animal sources to various advantages. A variety of

\footnotetext{
* Corresponding Author

E-mail:muruganbt@gmail.com
}

microorganisms such as bacteria, fungi, yeast and actinomycetes are known to produce these enzymes [5]. Even though most commercial proteases originated from microorganisms belonging to the genus Bacillus, fungi exhibit a wider variety of proteases than bacteria.

Furthermore, fungi are normally generally regarded as safe strains and they produce extracellular enzymes, which are easier to be recovered from fermentation broth molds of the genera Aspergillus, Penicillium and Rhizopus are especially useful for producing proteases, as several species of these genera are generally regarded as safe [6]. In the present investigation, protease producing fungi were isolated from soil sample, screened and identified. The enzyme was then produced in shake flask and the critical production parameters like $\mathrm{pH}$ and temperature were optimized.

\section{MATERIALS AND METHODS}

\subsection{Sample collection}

Soil samples were collected from five different paddy crop fields in various locations of Mannargudi Taluk, Tiruvarur Ditrict. The Soil samples of paddy crop fields at Mannargudi Taluk were collected during three intervals within a period of six months. The soil samples were collected from different crop fields (up to $15 \mathrm{~cm}$ depth) into a small sterilized polythene bags and brought to laboratory for further studies. 


\subsection{Isolation of fungi}

The soil fungi were enumerated by the Soil Dilution method using Potato Dextrose Agar. The medium was sterilized at $121^{\circ} \mathrm{C}$ for $15 \mathrm{~min}$ at $15 \mathrm{lbs}$ and $15 \mathrm{ml}$ of the sterile medium was dispensed into sterile petridishes and kept aside for further use. 1 $\mathrm{ml}$ of microbial suspension from $10^{-3}, 10^{-4}$ and $10^{-5}$ dilutions were added into sterile Petri dishes (triplicate of each dilution) containing $15 \mathrm{ml}$ of sterile Potato Dextrose Agar. 1\% streptomycin solution was added to the medium before pouring into petriplates for preventing bacterial growth. The Petri dishes were then incubated at $28^{\circ} \mathrm{C}$ in dark. The plates were observed everyday up to three days.

\subsection{Microscopic Identification of the soil fungi}

Fungal morphology were studied macroscopically by observing colony features (Colour and Texture) and microscopically by staining with lacto phenol cotton blue and observe under compound microscope for the conidia, conidiophores and arrangement of spores [7]. The fungi were identified with the help of literature $[8,9]$.

\subsection{Screening by Plate Assay Method}

Production of proteolytic enzymes by fungal isolates was detected by using the Plate assay method of Hankin and Anagnostakis [10], in which gelatin is the protein source of that growth medium. The fungal isolates were spot inoculated in petridishes with nutrient agar medium supplemented with $1 \%$ gelatin (Peptone, 5g; Beef extract, 3g; $\mathrm{NaCl}, 5 \mathrm{~g}$; Agar, 15g; Distilled water, 1 liter, $\mathrm{pH}$ 6). Following inoculation, the petridishes were incubated at $28 \pm 1^{\circ} \mathrm{C}$ for 3 days. After a week of incubation, gelatin degradation was observed as a clearing zone around fungal colonies.

This zone of gelatinolysis was seen clearly upon flooding the plate with aqueous saturated solution of mercuric chloride reagent $\left(15 \mathrm{~g} \mathrm{HgCl}_{2}\right.$ dissolved completely in $20 \mathrm{ml} 7 \mathrm{M}$ conc. $\mathrm{HCl}$, then raised to $100 \mathrm{ml}$ with sterile distilled water). Mercuric chloride solution reacted with gelatin to produce a white precipitate which made the clearing zone visible. The clearing zone was measured indicative of the extracellular protease activity of the fungal strain. Enzyme activity was measured by the following formula: EA = D-d; D- diameter of colony plus clearing zone; $d$ - diameter of colony. Two most potent isolates out of the six were chosen for further production and kinetic optimization studies.

\subsection{Protease production}

The selected two fungal isolates were inoculated in sterile $100 \mathrm{ml}$ of protease specific fermentation broth containing (\% w/v): yeast extract 1.0, MgSO4 0.02, glucose 2.0, $\mathrm{K}_{2} \mathrm{HPO}_{4} 0.1$, $\mathrm{pH}$ 7.0. Flasks, inoculated were incubated at $28^{\circ} \mathrm{C}$ for 5-6 days in a rotary shaker.

At the end of incubation, the contents of flasks were filtered through Whatmann filter paper No. 1 and then the filtrates were centrifuged at $8,000 \mathrm{rpm}$ at $4^{\circ} \mathrm{C}$ for 10 minutes. Pellet was discarded after centrifugation and clear supernatant was used as source of protease enzyme. The supernatant of crude enzyme was further used for subsequent studies [11].

\subsection{Measurement of enzyme activity}

Protease activity in the crude enzyme extract was determined according to the method of Carrie Cupp-Enyard by using casein as substrate. Two test tubes were taken and labeled as test (T) and blank (B). Five $\mathrm{mL}$ of $0.65 \%$ casein solution was added in test and blank tubes and test tubes were placed at $37{ }^{\circ} \mathrm{C}$ for 5 minutes. One $\mathrm{mL}$ of enzyme solution was added in T-test tube. It was mixed properly and incubated at $37^{\circ} \mathrm{C}$ in a water bath for $30 \mathrm{~min}$ for allowing the enzymatic reaction to occur. The reaction was terminated by addition of $5 \mathrm{~mL}$ of Trichloroacetic acid (TCA) solution in both test and blank tubes. One $\mathrm{mL}$ of enzyme solution was added in blank test tube only and it was allowed to stand for 15 minutes at room temperature. Solution from both test tubes was filtered using Whatmann No 1 filter paper.

Two $\mathrm{mL}$ of test and blank filtrate were taken in two new test tubes and labeled as test (T) and blank (B). Five $\mathrm{mL}$ of sodium carbonate was added in both test tubes followed by addition of 1 $\mathrm{mL}$ of 2 fold diluted Follin Ciocalteus phenol reagent. The resulting solutions in both test tubes were incubated in dark for 30 minutes at room temperature for the development of blue color. The absorbance of the blue color compound was measured at 660 $\mathrm{nm}$ against a reagent blank using tyrosine standard. One protease unit was defined as the amount of enzyme that releases $1 \mu \mathrm{M}$ of tyrosine per minute at $\mathrm{pH} 7.5$ at $37{ }^{\circ} \mathrm{C}$ [12]. All the experiments were done in triplicates and mean value was presented.

\subsection{Optimization of culture conditions for Protease enzyme production \\ 2.7.1 Effect of pH on Protease enzyme production}

To determine optimal $\mathrm{pH}$, fungus cultures were cultivated in a $150 \mathrm{~mL}$ flask containing $50 \mathrm{~mL}$ optimized medium with different $\mathrm{pH}$ ranges from 4.0 to 8.0. The $\mathrm{pH}$ of the medium was adjusted by using $1 \mathrm{~N} \mathrm{HCl}$ or $1 \mathrm{~N} \mathrm{NaOH}$. The flasks were kept in stationary stage at $28^{\circ} \mathrm{C}$ for 5 days of cultivation.

\subsection{Effect of temperature on Protease enzyme production}

In order to determine the effective temperature for protease production by the fungal species, fermentation was carried out at $5^{\circ} \mathrm{C}$ intervals in the range of $20,25,30,35$ and $40^{\circ} \mathrm{C}$.

\section{RESULT AND DISCUSSION}

Fungi occurring in natural habitats with changing environmental conditions are important from the industrial point of views. Fungal diversity of any soil depends on a large number of factors of the soil such as $\mathrm{pH}$, organic content, and moisture [13, 14]. They can be found producing novel metabolites or enzymes with hyper catalytic properties. 


\subsection{Isolation and identification of soil fungal isolates}

During the investigation period 105 fungal colonies of 6 fungal species (Aspergillus sparsusi, A. janthinellum, A.ochraceous, A. flavus, A.terreus and A.niger) were observed. The maximum fungal species belongs to Deuteromycotina. Among most isolates the genera Aspergillus were dominant.

The colony pigmentation was white, yellow - brown to black shades of green, grown evenly with dense felt erect conidiophores. The morphology of conidial heads on LPCB microscopic mounts showing hyaline; hyphomycetes with distinct conidial heads with flask shaped phialides arranged on vesicle were noticed. Generally identification of the Aspergillus species is based on the morphological characteristics of the colony and microscopic examinations [15]. Based on the results of cell morphology observers, these isolates belong the group of Aspergillus sp. that have the same characteristics, namely globular vesicles, conidiophores shaped translucent yellowish green, semi conidiaspore round to round-shaped light green to brownish green [16].

\subsection{Screening by Plate Assay Method}

Screening of fungi for their protease activity was carried out by the hydrolysis of substrate incorporating in the medium by plate assay method. After an incubation period, enzyme activities were detected by the appearance of zones around the fungal colonies. Two fungal species i.e. Aspergillus flavus and Aspergillus niger out of the total six isolates which showed highest zone around the colony, were used for further study. Among fungi species of certain genera, Aspergillus, Penicillium, Paecilomyces, Rhizopus and Rhizomucor are well-known producers of proteases $[17,18]$ and are reported active over a wide $\mathrm{pH}$ range [19].

\subsection{Optimization of kinetic parameters for enzyme production 3.3.1 Effect of $\mathrm{pH}$ on protease enzyme production}

Among physical parameters, $\mathrm{pH}$ of the growth medium plays an important role by inducing morphological changes in microbes and in enzyme secretion. The $\mathrm{pH}$ change observed during the growth of microbes also affects product stability in the medium. The optimal $\mathrm{pH}$ varies with different microorganisms and enzymes. Both the isolates were allowed to grow in media of different $\mathrm{pH}$ ranging from 4.0 to 8.0. Maximum enzyme production was observed in medium of $\mathrm{pH} 8.0$ in case of Aspergillus flavus $(30 \mathrm{IU} / \mathrm{ml})$ followed by $\mathrm{pH}$ of 7.0 in case of Aspergillus niger (26 IU/ml) (Fig 1).

It has been reported widely that protease production from microbial source can be acidic or alkaline proteases as reported by many researchers depending on the organisms and source of the isolation. Nascimento and Martins [20] and Sookkheo et al. [21] also reported the optimum $\mathrm{pH}$ for protease activity to be between 7.0 and 8.5. According to Borris [22] alkaline protease production is found to be higher at $\mathrm{pH} 9-13$. In similarly studies carried out by Sonia Sethi and Saksham Gupta [23] Maximum protease enzyme activity was observed in medium of $\mathrm{pH} 9.0$ in case of Penicillium chrysogenum followed by Aspergillus niger.

\subsection{Effect of temperature on protease enzyme production}

Incubation temperature plays an important role in the metabolic activities of a microorganism. Even slight changes in temperature can affect enzyme production. Presently, the optimal temperature for maximum protease production was studied by incubation of the inoculated media at different temperature ranging from $20-45^{\circ} \mathrm{C}$ and enzyme production was found to be highest at $30^{\circ} \mathrm{C}$. However, the enzyme was completely inactivated at $45^{\circ} \mathrm{C}$. The results of the test made at different temperature values showed that the optimal temperature for protease production $(26 \mathrm{IU} / \mathrm{mL})$ by $A$. flavus was at $30^{\circ} \mathrm{C}$ (Fig 2) and $32 \mathrm{IU} / \mathrm{ml}$ for $A$. niger at $35^{\circ} \mathrm{C}$.

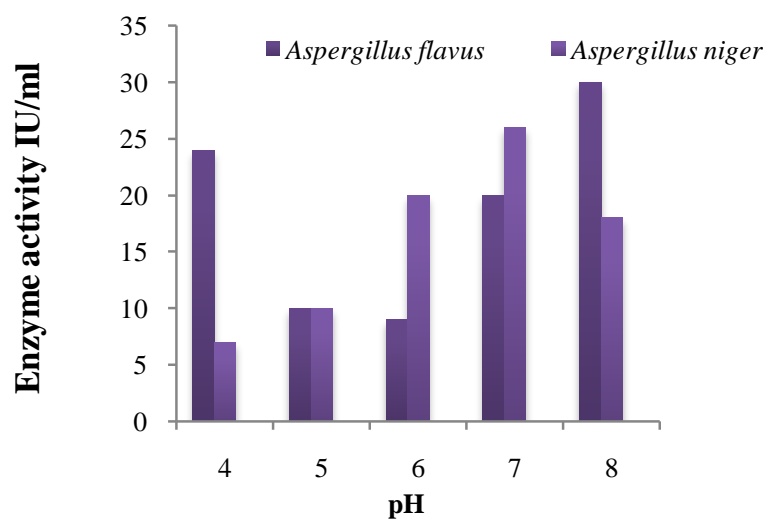

Fig. 1: Effect of $\mathrm{pH}$ on Protease production.

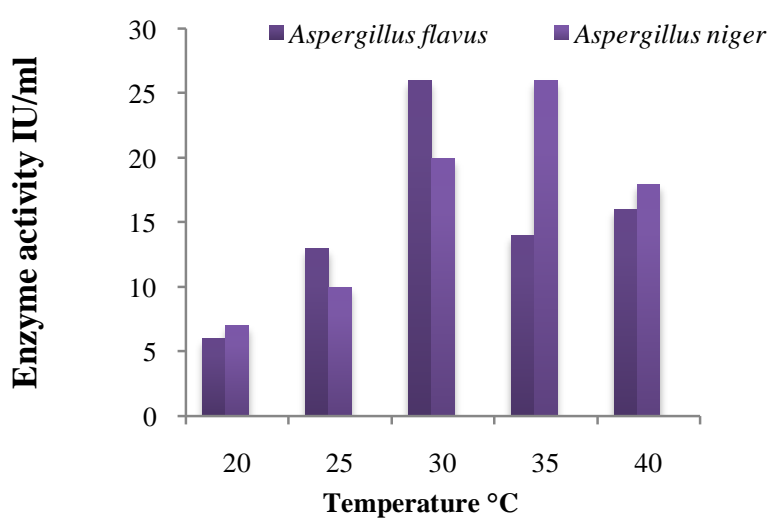

Fig. 2: Effect of temperature on Protease production.

Since enzyme is a secondary metabolite produced during exponential growth phase, the incubation at high temperature could lead to poor growth and thus a reduction in enzyme yield [24]. Similarly, Ganesh Kumar et al., [25] reported the optimum temperature for protease production by the mesophilic fungi Synergistes species was at $35^{\circ} \mathrm{C}$. Growth and protease production ceased at higher temperatures $\left(50^{\circ} \mathrm{C}\right)$ Similar observation were shown by Morimura et al. [26] for Aspergillus usami.

Based on the results, major parameters affecting the fermentation process for enzyme production were studied and optimal levels were identified. Enzyme production is closely controlled in microorganisms and for improving its productivity, these controls can be ameliorated. Proteases yields appear to depend on a complex relationship involving a variety of factors 
like inoculum size, $\mathrm{pH}$ value, temperature, aeration, growth time, and so forth. This study has given a hint that microbial wealth of protease producing fungi isolated from soil can be harnessed for biotechnological processes. The appreciable high enzyme activity at $\mathrm{pH}(\mathrm{pH} 8.0$ and 7.0) suggested that A.flavus and A.niger are potential producers of proteases which can find application in various industries. Also further purification of this protease enzyme studies yet to be carried out. In conclusion microorganisms especially fungi present in the soil like Aspergillus flavus, Aspergillus niger, Aspergillus fumigatus and Penicillum sp. produce hydrolytic enzymes of industrial and biotechnological importance. The protease enzyme from these fungi has ability to degrade the proteolytic materials which find varied application in many fields.

\section{REFERENCES}

1. Biesebeke R, Boussier A, Van Biezen N, Van den Hondeland CA, Punt PJ. Identification of secreted proteins of Aspergillus oryzae associated with growth on solid cereal substrates Journal of Biotechnology. 206; 24: 482-485.

2. Prescott LM, Harley JP, Klein DA. Microbiology. vol.1 (Ed. 2nd). W.M.C. Brown Publishers. 1993; p.992.

3. Dias DR, Vilela DM, Silvestre MPC, Schwan RF. Alkaline protease from Bacillus sp. isolated from coffee bean grown on cheese whey. World Journal of Microbiology and Biotechnology. 2008; 24 (10): 2027-2034.

4. Gupta R, Beg QK, Khan S, Chauhan B. An overview on fermentation, downstream processing and properties of microbial proteases. Appl Microbiol Biotechnol. 2002; 60: 381-395.

5. Madan M, Dhillon S, Singh R. Production of alkaline protease by a UV mutant of Bacillus polymyxa. Ind. J. Microbiol. 2002; 42: 155159

6. Sandhya C, Sumantha A, Szakacs G, Pandey A. Comparative evaluation of neutral protease production by Aspergillus oryzae in submerged and solid-state fermentation. Process Biochem. 2005; 40: 2689-2694

7. Aneja KR. Experiments in Microbiology, Pant pathology and Biotechnology, Newage International Publishers. 2001; 4: 157-162.

8. Gilman JC. A Manual of Soil fungi, 2nd Indian edition, Biotech Books, Delhi, 2001

9. Nagamani A, Kunwar IK, Manoharachary C. Hand book of soil fungi, I.K.International Pvt.Ltd, 2006.

10. Hankin L, Anagnostakis SL. Mycologia. 1975; 67: 597. 607.

11. Josephine SF, Ramya VS, Neelam D, Suresh BG, Siddalingeshwara $\mathrm{KG}$ Venugopal $\mathrm{N}$ and Vishwanatha TJ. Isolation, production and characterization of protease from Bacillus $S p$ isolated from soil sample. Microbiol. Biotech. Res. 2012; 2 (1):163-168.

12. Mohapatra BR, Bapuji M, Sree A. Production of industrial enzymes (amylase, Carb oxymethylcellulase and protease) by bacteria isolated from marine sedentary organisms. Acta Biotechnol. 2003; 23: 75-84.
13. Alexander M. Introduction to soil Microbiology. John Wiley \&Sons, New York. 1977.

14. Rangaswami G, Bagyaraj DJ. Agricultural Microbiology, Ind edition published by Prentice Hall of India Pvt. Ltd. N. Delhi, 1998.

15. McClenny N. Laboratory detection and identification of Aspergillus species by microscopic observation and clture. J. Md. Mycol. 2005; 1 125-128.

16. Yunasfi. Fungi at Eucalyptus urophylla S.T. Blake in Log Yard (TPK) PT. Toba Lestari, Tbk, 2008.

17. Sindhu R, Suprabha GN, Shashidhar S. Optimization of process parameters for the production of alkaline protease from Penicillium godlewskii SBSS 25 and its application in detergent industry. Afri. J. Microbiol Res. 2009; 3 (9): 515-522.

18. Vamsi Krishna K, Gupta M, Gupta N, Gaudani H, Trivedi S, Patil P, Gupta G, Khairnar Y, Barasate A, Mishra D. Optimization of growth and production of protease by Penicillium species using submerged fermentation. Int. J. Microbiol. Res. 2009; 1 (1): 14-18.

19. Rao MB, Tanksale AM, Ghatge MS, Deshpande VV. Molecular and biotechnological aspects of microbial protease. Microbial Molbiol Rev. 1998; 62:597-635.

20. Nascimento CA, Martin MLL. Production and properties of extracellular protease from thermophilic Bacillus sp. Brazilian J. Microbiology. 2004; 35: 91-96.

21. Sookkheo B, Sinchaikul S, Phutrakul S, Chen ST. Purification and characterization of the highly thermostable proteases from Bacillus stearothermophilus TLS33.Prot. Exp. Purif. 2000; 20: 142-151.

22. Borriss R. Biology of enzymes. In: (Rehm H \& Reed G. eds) Biotechnology. Weinheim, Verlag chemie. 1987; pp. 35-62.

23. Sonia Sethi and Saksham Gupta. Optimization of protease production from fungi isolated from soil.InJj of Applied Biol. \& Pharm. 2015; 6 (3): 149-153.

24. Sabu A, Sarita S, Pandey A, Bogar B, Szakacs G, Socol CR. SolidState Fermentation for Production of Phytase by Rhizopus oligosporus. Apl Biochem Biotechnol. 2012; 103: 251-260.

25. Ganesh Kumar A, Nagesh N, Prabhakar TG, Sekharan G. Purification of extracellular acid protease and analysis of fermentation metabolites by Synergistes sp. utilizing proteinaceous solid waste from tanneries, Bioresource Technol. 2008; 99 (7): 2364-2372.

26. Morimura S, Kida, Sonada Y. Production of protease using waste water from the manufacture of Shochu. J.Ferment.Bioeng. 1994; 77 183-187.

\section{How to cite this article:}

Sudarkodi C, Sundar SK, Murugan M. Production and Optimization of Protease By Filamentous Fungus Isolated From Paddy Soil In Thiruvarur District Tamilnadu. J App Biol Biotech, 2015; 3 (06): 066-069. DOI: 10.7324/JABB.2015.3610 